\title{
Rozróżnienie immunitetu państwa oraz immunitetów dyplomatycznych
}

Z prawa międzynarodowego wywodzą się różnego rodzaju zwolnienia od jurysdykcji lub egzekucji państwa forum, tj. immunitety, przysługujące państwom lub ukonstytuowanym przez nie organizacjom międzynarodowym. Prawa te przysługują różnym podmiotom, mają różny zakres i skutki. Wziąwszy pod uwagę częste w praktyce mylenie immunitetów ${ }^{1}$, celowe wydaje się przypomnienie na wstępie ich głównych rodzajów. Najczęściej jednak mylony jest immunitet państwa i immunitety dyplomatyczne. Niniejszy artykuł poświęcimy wskazaniu zasadniczych różnic i podobieństw między tymi dwoma kategoriami oraz problemów pojawiających się przy ich stosowaniu. Rozważania te opieramy na praktyce polskich sądów ${ }^{2}$. Pojęcie immunitetu, jakie stosujemy w niniejszym artykule, oznacza prawo niepodlegania jurysdykcji lub egzekucji państwa forum.

${ }^{1}$ Przykładowo w sprawie Marta M. przeciwko Konsulatowi Generalnemu Republiki Federalnej Niemiec (postanowienie z 18 marca 1998 r. I PKN 26/98, OSNAP 1999/5/172) w K. o uznanie wypowiedzenia umowy o pracę za bezskuteczne Sąd Najwyższy, a także sądy rozpatrujące tę sprawę wcześniej, miał trudności z rozróżnieniem immunitetu państwa, immunitetów konsularnych i dyplomatycznych. Sąd błędnie uznał, że skoro umowa o pracę dotycząca zatrudnienia w dziale wizowym konsulatu (biurze administracyjnym konsulatu) została zawarta przez konsula generalnego, jest on pracodawcą, co więcej, korzysta z immunitetu dyplomatycznego wynikającego z Konwencji o stosunkach dyplomatycznych z 1961 r. Sąd odwołał się co prawda najpierw do Konwencji o stosunkach konsularnych z 1963 r., ale dalej z niewiadomych przyczyn oparł się na Konwencji z $1961 \mathrm{r}$. Stwierdził nawet wyraźnie, że „Wyłączenie sporów ze stosunku pracy, w których pracodawcą jest konsul działający jako przedstawiciel państwa wysyłającego, z immunitetu od jurysdykcji państwa przyjmującego godziłoby niewątpliwie w istotę immunitetu dyplomatycznego".

2 Zob. A. Wyrozumska, Polskie sądy wobec immunitetu państwa obcego, PiP 2000, z. 3; P. Grzegorczyk, Immunitet państwa w postępowaniu cywilnym, Warszawa 2010. 


\section{Rodzaje immunitetów wywodzących się z prawa międzynarodowego}

Jedną z najstarszych zasad prawa międzynarodowego, którą znali z pewnością już starożytni Grecy i Rzymianie, jest zasada nietykalności przedstawicieli dyplomatycznych obcego państwa, w tym niepodlegania jakiejkolwiek formie zatrzymania lub aresztu. Dopiero jednak w XVI w. zaczął kształtować się immunitet jurysdykcyjny przedstawicieli dyplomatycznych; pełny w przypadku jurysdykcji karnej, ograniczony w przypadku jurysdykcji w sprawach cywilnych ${ }^{3}$. Immunitety dyplomatyczne przysługujące misji dyplomatycznej i osobom z nią związanym, reguluje Konwencja wiedeńska o stosunkach dyplomatycznych z $1961 \mathrm{r}$. W latach 60. niektóre z postanowień tej Konwencji mogły być uważane za postępowy rozwój prawa międzynarodowego. Konwencja kształtowała jednak konsekwentnie praktykę państw.

Od immunitetów dyplomatycznych odróżnić trzeba przede wszystkim immunitety najwyższych przedstawicieli państwa $\mathrm{w}$ stosunkach międzynarodowych $\mathrm{tj}$.: głowy państwa, premiera oraz ministra spraw zagranicznych. Praktyka sądowa w odniesieniu do tych osób nie jest zbyt bogata, niemniej należy odnotować przede wszystkim orzeczenie Międzynarodowego Trybunału Sprawiedliwości w sprawie nakazu aresztowania z 11 kwietnia 2000 r., Kongo przeciwko Belgii. W sprawie tej MTS podkreślił, że osoby te korzystają z absolutnego immunitetu jurysdykcyjnego przysługującego im ratione personae podczas wykonywania funkcji ${ }^{4}$.

Z przywileju niepodlegania jurysdykcji państwa forum korzystają także placówki konsularne i osoby $\mathbf{z}$ nimi związane. Kwestie te reguluje m.in. art. 43 Konwencji wiedeńskiej o stosunkach konsularnych z 1963 r., który stanowi, że funkcjonariusze konsularni i pracownicy konsularni nie podlegają jurysdykcji władz sądowych i administracyjnych państwa przyjmującego w odniesieniu do czynności wykonywanych w związku z pełnieniem funkcji konsularnych. Immunitet konsularny przysługuje zatem w stosunku do czynności wykonywanych w związku z pełnieniem funkcji konsularnych.

Podobnie z immunitetu ograniczonego do wykonywanych funkcji korzystają osoby uczestniczące $w$ misjach specjalnych ${ }^{5}$, misjach przy organizacjach międzynarodowych ${ }^{6}$, delegacjach do organizacji lub organów międzynarodowych, na konferencjach międzynarodowych oraz osoby z nimi związane ${ }^{7}$.

${ }^{3}$ R. van Alebeek, Immunity, Diplomatic, [w:] Max Planck Encyclopedia of International Law, online edition, red. R. Wolfrum.

${ }^{4}$ Sprawa nakazu aresztowania z 11 kwietnia 2000 r. Kongo v. Belgii, ICJ Reports 2002, pkt 54.

${ }_{5}$ Zob. np. Konwencja wiedeńska o misjach specjalnych z 1969 r.

${ }^{6}$ Zob. np. Konwencja wiedeńska o reprezentacji państw w ich stosunkach z organizacjami międzynarodowymi o charakterze powszechnym z $1975 \mathrm{r}$.

${ }^{7}$ Zob. w ten sposób np. art. 3 Konwencji NZ o immunitetach jurysdykcyjnych państw i ich własności z 2004 r. 
Od przysługujących państwu immunitetów związanych z określonymi osobami wykonującymi w jego imieniu różne funkcje odróżnić trzeba immunitet państwa. Immunitet ten jako zasada prawa międzynarodowego ukształtował się dopiero w początkach XIX w. Do tego czasu dominowała wskazana wyżej w ogólnych zarysach konstrukcja immunitetów personalnych związanych początkowo $\mathrm{z}$ osobą obcego suwerena lub jego przedstawicielami dyplomatycznymi. Po raz pierwszy odwołał się do immunitetu państwa w 1812 r. sędzia Sądu Najwyższego Stanów Zjednoczonych - Marshall - w sprawie The Schooner Exchange v. M'Faden'owi i innym. W swojej opinii sędzia Marshall podkreślił z jednej strony wyłączny i absolutny charakter jurysdykcji państwa w obrębie swojego terytorium, z drugiej strony wskazał na konieczność opartych na zgodzie wyjątków z uwagi na poszanowanie innej, równej i niezależnej „suwerenności”. Zgoda ta „może być w pewnych przypadkach testowana przez wspólną praktykę (common usage), i wspólną opinię z niej wyrastającą" (consent may, in some instances, be tested by common usage, and by common opinion, growing out of that usage). Prawo zwyczajowe w tej dziedzinie rozwijały następnie sądy krajowe, przede wszystkim Stanów Zjednoczonych i Zjednoczonego Królestwa, a także Francji, Belgii, Austrii itp. Początkowo dominowała w praktyce koncepcja całkowitego niepodlegania obcego państwa jurysdykcji państwa forum (immunitet absolutny). W miarę jednak rozwoju przede wszystkim stosunków handlowych, praktyka dopuściła szereg wyjątków. Tendencję tę oddaje najpełniej Konwencja NZ o immunitetach jurysdykcyjnych państw i ich własności z 2004 r. (immunitet państwa ma zgodnie z Konwencją charakter ograniczony).

Immunitet państwa odróżnić trzeba nie tylko od np. immunitetów dyplomatycznych, ale także od immunitetu sił zbrojnych państwa. Immunitet sil zbrojnych państwa obcego regulowany jest często umowami dwustronnymi lub wielostronnymi (np. tzw. NATO SOFA, tj. Umową między Państwami-Stronami Traktatu Północnoatlantyckiego dotyczącą statusu ich sił zbrojnych, sporządzoną w Londynie dnia 19 czerwca 1951 r.), a także np. rezolucjami ONZ lub ustawami krajowymi. Nie ma zatem powszechnej umowy międzynarodowej regulującej te kwestie.

Z immunitetów korzystają obok państw także organizacje międzynarodowe i ich funkcjonariusze. Zakres tych immunitetów regulowany jest często w umowach konstytuujących te organizacje lub w odrębnych umowach zawieranych z państwami członkowskimi ${ }^{8}$. W tym zakresie warto odnotować orzeczenie Europejskiego Trybunału Praw Człowieka uznające immunitet organizacji międzynarodowej w sprawie Waite $i$ Kennedy v. Niemcom z 1999 ${ }^{9}$. W sprawie tej skarżący wszczęli postępowanie przed sądami niemieckimi przeciwko Europejskiej Agencji Przestrzeni Kosmicznej (European Space Agency). Chodziło o ustalenie ich statusu jako pracowników tej organizacji. Postępowanie zostało umorzone

${ }^{8}$ Zob. np. Konwencja o przywilejach i immunitetach Narodów Zjednoczonych z 1946 r.

9 [1999] I ECHR Reports 393. 
z uwagi na immunitet jurysdykcyjny wynikający z Konwencji z 1975 r. konstytuującej tę organizację. Trybunał badał, czy tego typu ograniczenie prawa do sądu jest zgodne z art. 6 ust. 1 Europejskiej Konwencji Praw Człowieka. Trybunał nie stwierdził naruszenia Konwencji. Podkreślił przy tym m.in., że przyznanie organizacjom międzynarodowym przywilejów i immunitetów stanowi podstawowy środek zapewniania właściwego funkcjonowania takich organizacji wolnego od jednostronnej ingerencji poszczególnych rządów i stąd jego cel jest uprawniony.

Najważniejsze umowy międzynarodowe, odnoszące się do różnego typu immunitetów podkreślają odmienność ich reżimów prawnych poprzez postanowienia, takie jak np. art. 3 Konwencji NZ z 2004 r. dotyczącej immunitetu państwa. Przepis ten wskazuje m.in., że Konwencja nie narusza przywilejów i immunitetów, z których korzystają państwa, w odniesieniu do wykonywania funkcji misji dyplomatycznych, placówek konsularnych, misji przy organizacjach międzynarodowych lub delegacji do organów międzynarodowych organizacji lub konferencji międzynarodowych oraz osób z nimi związanych. Konwencja nie narusza także przywilejów i immunitetów przyznanych przez prawo międzynarodowe głowom państw ratione personae, a także przyznanych państwom w odniesieniu do samolotów powietrznych lub obiektów kosmicznych stanowiących własność lub użytkowanych (operated) przez państwa. Podobnie Europejska konwencja o immunitecie państwa podpisana w Bazylei w 1972 r. w art. 32 stwierdza, że „żadne postanowienie niniejszej konwencji nie narusza przywilejów i immunitetów związanych z wykonywaniem funkcji misji dyplomatycznych i urzędów konsularnych, a także osób, które są z nimi związane". W komentarzu do Konwencji wyjaśniono, że „te przywileje i immunitety odpowiadają innym potrzebom aniżeli te, które usprawiedliwiają niniejszą konwencję” oraz że „nie naruszają ich one ani bezpośrednio, ani pośrednio".

Zwolnienia od jurysdykcji państwa forum dotyczyć mogą postępowania sądowego lub fazy egzekucji wyroku. Dlatego wyróżnić trzeba immunitety jurysdykcyjny i egzekucyjny.

\section{Immunitet państwa a immunitety dyplomatyczne}

Immunitet państwa i immunitety dyplomatyczne łączy z pewnością jedna istotna wspólna cecha, a mianowicie obydwa rodzaje immunitetów stanowią atrybut państwa. Konsekwencją tego jest to, że zarówno immunitetu państwa, jak i immunitetów dyplomatycznych może zrzec się tylko państwo (zob. np. art. 7 Konwencji NZ z 2004 r., art. 32 Konwencji wiedeńskiej o stosunkach dyplomatycznych z 1961 r.). Immunitet państwa oraz immunitety dyplomatyczne łączy ta sama terminologia i niektóre skutki, są to jednak różne reżimy prawne. 
Zauważył to świetnie polski Sąd Najwyższy w wyroku z 14 grudnia $1948 \mathrm{r}$. w sprawie Aldona S. v. Wielkiej Brytanii ${ }^{10}$ : ,Jeżeli istnieje pewna zbieżność w niektórych skutkach dla immunitetów, tłumaczy się ona przypadkową koincydencją pewnych konsekwencji tych immunitetów; to jednak, że z odmiennych przyczyn mogą wyniknąc podobne skutki, nie daje podstawy do podciągnięcia zasadniczo odmiennego immunitetu obcego państwa pod przepisy kodeksu postępowania cywilnego, dotyczące immunitetów dyplomatycznych, mianowicie pod przepisy art. 5 tego kodeksu. Przy rozstrzyganiu przeto kwestii, dotyczących immunitetu sądowego państw obcych, należy oprzeć się bezpośrednio na ogólnych zasadach, powszechnie przyjętych w obrocie międzynarodowym".

Immunitety państwa i dyplomatyczne różnią się także co do podmiotów, do których mają zastosowanie. Immunitet państwa odnosi się do wszelkich organów i jednostek organizacyjnych państwa obcego, immunitety dyplomatyczne odnoszą się do misji dyplomatycznej państwa wysyłającego oraz osób związanych z nią. Widać tu jednak wspólny zakres obu rodzajów immunitetu, misja dyplomatyczna stanowi jednostkę organizacyjną państwa obcego, objęta jest ona zarówno immunitetem państwa, jak i immunitetami dyplomatycznymi. Misja dyplomatyczna w ramach prawa dyplomatycznego korzysta jednak li tylko z nietykalności pomieszczeń, archiwów itp. Natomiast gdy chodzi np. o działania lub zaniechania przedstawicieli dyplomatycznych, to w konkretnym przypadku mogą oni korzystać z ochrony immunitetu dyplomatycznego (immunitet ten przysługuje ratione personae). Oznacza to np. zwolnienie dyplomaty od jurysdykcji państwa forum. Skoro jednak to samo działanie lub zaniechanie dyplomaty może zostać przypisane państwu, to postępowanie w państwie forum może zostać wszczęte przeciwko państwu. Wówczas zastosowanie ma reżim prawny immunitetu państwa, który przewiduje szereg ograniczeń na rzecz jurysdykcji państwa forum.

Nie jest trudno o pomyłkę zwłaszcza, gdy przyjmie się pogląd, że immunitet państwa ma charakter absolutny. Przykładem jest uchwała składu siedmiu sędziów Sądu Najwyższego z 26 września 1990 r. ${ }^{11}$ w sprawie z powództwa Andrzeja B. $i$ Wiesława B. przeciwko Centrum Techniki Samochodowej $w$ W. o zapłatę (Centrum to stanowiło jednostkę przedstawicielstwa handlowego stanowiącego z kolei część Ambasady ZSRR). Sąd Najwyższy pomylił podstawy i zakresy immunitetu państwa i immunitetów dyplomatycznych. Słusznie wnosił, że sprawa ma związek z immunitetem państwa, ale podstawę prawną dla tego immunitetu widział w Konwencji o stosunkach dyplomatycznych. Zdaniem Sądu, przedstawicielstwo dyplomatyczne obcego państwa korzysta z immunitetu od jurysdykcji państwa przyjmującego. Ta zasada ,uznana i respektowana przez cywilizowaną społeczność międzynarodową utrwalona została m.in. w art. 31 ust. 1 Konwencji wiedeńskiej o stosunkach dyplomatycznych". Trzeba tu podkreślić, że art. 31 ust. 1

${ }^{10}$ Sprawa C 635/48. Zob. PiP 1949, nr 4, s. 119 i nast.

11 III PZP 9/90, OSNC 1991/2-3/17. 
odnosi się jedynie do immunitetu jurysdykcyjnego przedstawiciela dyplomatycznego (a więc immunitetu przysługującego ratione personae). Sąd wyjaśnił dalej, że ,podstawową przesłanką uzasadniającą wyłączenie przedstawicielstwa dyplomatycznego od jurysdykcji sądów polskich jest suwerenność państwa wysyłającego, albowiem istnieje oczywisty i niezaprzeczalny związek między immunitetem jurysdykcyjnym państwa a przywilejami i immunitetami jego organów. Żadne suwerenne i niepodległe państwo jako podmiot prawa międzynarodowego nie jest podporządkowane prawu innego państwa".

Immunitetom, o których tu mowa, przyświeca jednak zupełnie różny cel. Podczas gdy celem immunitetu państwa jest ochrona suwerenności państwa przez zwolnienie od jurysdykcji państwa forum aktów państwa obcego podejmowanych w wykonywaniu jego funkcji władczych wyrażona paremią par in parem non habet imperium, celem immunitetów dyplomatycznych jest jedynie umożliwienie wykonywania funkcji dyplomatycznych bez jakichkolwiek przeszkód, a zatem nieprzeszkadzanie - ne impediatur legatio. Świetnie dostrzegał tę różnicę polski Sąd Najwyższy w wyroku z 14 grudnia 1948 r. w sprawie Aldona S. przeciwko Wielkiej Brytanii ${ }^{12}$, odmawiając możliwości zastosowania przepisów k.p.c. z 1932 r. odnoszących się do cudzoziemców (art. 4) lub osób korzystających z immunitetów dyplomatycznych (art. 5) do pozwanego państwa. Sąd słusznie podkreślił, że podstawa prawna immunitetu przedstawiciela dyplomatycznego jest inna aniżeli podstawa prawna immunitetu państwa. Podstawą immunitetu przedstawicieli dyplomatycznych jest zasada swobody wykonywania ich funkcji - ne impediatur legatio, natomiast podstawą immunitetu państw obcych jest „demokratyczna zasada ich równości bez względu na ich wielkość i powagę, w konsekwencji wyłączająca jurysdykcję jednego państwa nad innym (par in parem non habet judicium)".

Inne są również źródła obu rodzajów immunitetów. Immunitet państwa ma swoją podstawę głównie w prawie zwyczajowym oraz w umowach międzynarodowych, takich jak np. Europejska konwencja o immunitecie państwa z 1972 r. czy Konwencja NZ o immunitetach jurysdykcyjnych państw i ich własności z 2004 r. Pamiętać jednak należy, że umowy międzynarodowe wiążą tylko strony. Pierwsza z Konwencji weszła w życie w 1976 r., ma niewielki zasięg, wiąże bowiem zaledwie 8 państw. Druga z Konwencji, która z założenia miała mieć charakter powszechny, nie weszła jeszcze w życie, podpisało ją 28 państw (Polska Konwencji nawet nie podpisała), 11 państw ją ratyfikowało. Ciągle zatem immunitet państwa opiera się przede wszystkim na prawie zwyczajowym.

Podstawą immunitetów dyplomatycznych jest natomiast Konwencja wiedeńska o stosunkach dyplomatycznych z 1961 r., która weszła w życie w 1964 r., wiąże obecnie aż 187 państw, a ponadto odzwierciedla prawo zwyczajowe.

${ }^{12}$ Sprawa C 635/48. Zob. PiP 1949, nr 4, s. 119 i nast. 
Omawiane immunitety różni jednak głównie ich zakres. Immunitet państwa opiera się na rozróżnieniu acta de iure gestionis oraz acta de iure imperii. Przy czym chroni on tylko te ostatnie czynności. Immunitety dyplomatyczne przysługują natomiast rationne personae w odniesieniu do wszelkich działań podejmowanych w imieniu państwa wysyłającego, bez względu na naturę aktu, którego dotyczą ${ }^{13}$. Dotyczą także własności misji. Nie są rządzone podziałem czynności na de iure imperii i de iure gestionis.

W konsekwencji, po pierwsze, czynność dokonana przez przedstawiciela dyplomatycznego może być przedmiotem postępowania przeciwko państwu, natomiast może nie być możliwe postępowanie przeciwko przedstawicielowi dyplomatycznemu.

Po drugie, państwo nie korzysta z immunitetu w stosunku do czynności de iure gestionis, ale gdy czynności takiej dokonuje przedstawiciel dyplomatyczny, może on korzystać z ochrony immunitetu dyplomatycznego, a ściśle - dyplomata dokonujący takiej czynności korzysta z immunitetu.

Po trzecie, immunitet dyplomatyczny w stosunku do czynności urzędowych nie jest zaledwie refleksem immunitetu państwa wysyłającego, lecz ma swoją niezależną podstawę w specjalnym statusie dyplomaty ${ }^{14}$.

${ }^{13}$ Podkreślić trzeba, że zgodnie z art. 31 Konwencji wiedeńskiej z 1961 r. immunitety dyplomatyczne przysługują państwu i nie obejmują czynności prywatnych przedstawiciela dyplomatycznego. Artykuł 31 stanowi:

„1. Przedstawiciel dyplomatyczny korzysta z immunitetu od jurysdykcji karnej państwa przyjmującego. Korzysta on również z immunitetu od jurysdykcji cywilnej i administracyjnej tegoż państwa, z wyjątkiem:

a) powództw z zakresu prawa rzeczowego dotyczących prywatnego mienia nieruchomego położonego na terytorium państwa przyjmującego, chyba że posiada on je w imieniu państwa wysyłającego dla celów misji;

b) powództw dotyczących spadkobrania, w których przedstawiciel dyplomatyczny występuje jako wykonawca testamentu, administrator, spadkobierca lub zapisobierca w charakterze osoby prywatnej, a nie w imieniu państwa wysyłającego;

c) powództw dotyczących wszelkiego rodzaju zawodowej lub handlowej działalności wykonywanej przez przedstawiciela dyplomatycznego w państwie przyjmującym poza jego funkcjami urzędowymi.

2. Przedstawiciel dyplomatyczny nie jest obowiązany do składania zeznań w charakterze świadka.

3. W stosunku do przedstawiciela dyplomatycznego nie mogą być przedsięwzięte żadne środki egzekucyjne, z wyjątkiem przypadków przewidzianych w punktach (a), (b) i (c) ustępu 1 niniejszego artykułu, z zastrzeżeniem jednak, że odnośne środki mogą być przedsięwzięte bez naruszania nietykalności jego osoby lub rezydencji.

4. Immunitet przedstawiciela dyplomatycznego od jurysdykcji państwa przyjmującego nie uchyla w stosunku do niego jurysdykcji państwa wysyłającego".

${ }^{14}$ W ten sposób np. niemiecki Federalny Sąd Konstytucyjny w wyroku z 10 czerwca 1997 r. $[\mathrm{D} / 16]$. 


\section{Odróżnianie immunitetów w praktyce}

Niektóre polskie sądy dość wcześnie zaczęły odróżniać immunitet państwa od immunitetów dyplomatycznych czy konsularnych. Pomijamy okres międzywojenny przykładowo w postanowieniu z 26 marca 1958 r. w sprawie wniesionej przeciwko Konsulatowi Francuskiemu w Krakowie ${ }^{15}$ Sąd Najwyższy podkreślił, że „powodowie pozywają Konsulat Francuski w Krakowie (nie Konsula osobiście), a więc Republikę Francuską", a to wysuwa na plan pierwszy zagadnienie, czy obce państwo podlega jurysdykcji sądów polskich. W sprawie Marii B.-L. przeciwko Instytutowi Kultury Austriackiej $w$ Warszawie o przywrócenie do pracy (wyrok z 25 marca 1987 r.) Sąd Najwyższy odrzucił możliwość zastosowania przepisów k.p.c. dotyczących immunitetów dyplomatycznych (art. 1111 ust. 1 pkt. 1 i 2) do instytucji rządowej państwa obcego - Instytutu Kultury Austriackiej, którego dyrektorem był jednocześnie radca kulturalny Ambasady Austrii w Polsce, rozważał natomiast postawioną przed nim kwestię w świetle immunitetu państwa.

Pamiętamy, że w uchwale składu siedmiu sędziów SN z 26 września 1990 r. ${ }^{16}$ Sąd Najwyższy nie bardzo radził sobie z immunitetem państwa. W latach 90. trzeba zatem odnotować orzeczenia sądów niższych, które wyraźnie dystansowały się od stanowiska zajętego przez Sąd Najwyższy. W postanowieniu z 23 września 1998 r. w sprawie Aleksander G. przeciwko Ambasadzie Portugalii ${ }^{17}$ o zapłatę czynszu za najem nieruchomości Sąd Rejonowy odrzucił stanowisko Sądu Najwyższego wyrażone w uchwale z 1990 r. i oparł się na konstrukcji immunitetu państwa, który, jego zdaniem, wywodzony być powinien z zasady suwerenności państw, ich wzajemnej równości i niezależności, co znajduje podstawę w umowach międzynarodowych i przyjętych zwyczajach. Podobnie w postanowieniu z 2 października 1997 r. w sprawie Katarzyna J. przeciwko Ambasadzie Chile ${ }^{18}$ Sąd Rejonowy uznał, że pozew skierowany przeciwko placówce dyplomatycznej obcego państwa faktycznie jest pozwem skierowanym przeciwko innemu państwu, chodzi zatem o immunitet państwa. Sąd uznał co prawda, że immunitet ten ma charakter immunitetu absolutnego, gdyż zgodnie z tradycją międzynarodową przyjmuje się, iż „równy w stosunku do równego nie ma władzy, ani jurysdykcji”"

Za swego rodzaju przełom trzeba uznać, aczkolwiek lakoniczne, postanowienie Sądu Najwyższego z 11 stycznia $2000 \mathrm{r}^{20}{ }^{\mathrm{w}}$ sprawie M. K. przeciwko Ambasadzie Chile o uznanie bezskuteczności wypowiedzenia umowy o pracę. Sąd odrzucił

152 CR 172/56, OSP 1959, poz. 160.

16 III PZP 9/90, OSNC 1991/2-3/17.

${ }^{17}$ Sąd Rejonowy dla m. st. Warszawy, sygn. III C 309/98.

18 Sąd Rejonowy dla Warszawy Pragi, sygn. VIII P 727/97.

${ }^{19}$ Do prawa zwyczajowego odwołał się sąd również w sprawach VIII P 2398/98 Mirosława N. przeciwko Ambasada Stanów Zjednoczonych Meksyku; III C 309/98 Aleksander G. przeciwko Ambasada Portugalii, w mniej wyraźny sposób w sprawie II C 9888/97.

${ }^{20}$ I PKN 562/99, OSNP 2000, Nr 19, poz. 723. 
wyraźnie możliwość zastosowania immunitetów dyplomatycznych, a konstrukcję immunitetu państwa osadził w prawie zwyczajowym. Odszedł przy tym od immunitetu absolutnego. Sąd podkreślił, że immunitet państwa przysługuje jedynie w odniesieniu do czynności de iure imperii, a nie do czynności de iure gestionis, do której to kategorii należą działania państwa w charakterze pracodawcy. Niestety niewiele później Sąd Najwyższy aczkolwiek oparł się na rozróżnieniu czynności de iure gestionis i uznał polską jurysdykcję, utożsamił nawet pojęcie immunitetu państwa z suwerennością, to jednak błędnie stwierdził, że immunitet państwa jest chroniony Konwencją o stosunkach dyplomatycznych (wyrok SN z 13 listopada $2003 \mathrm{r}^{21}$ ).

Prawdziwym przełomem jest natomiast bez wątpienia wyrok Sądu Najwyższego z 29 października 2010 r. IV CSK 465/09 w sprawie $W$. Natoniewski przeciwko Republice Federalnej Niemiec stanowiący najbardziej pełną wypowiedź Sądu w kwestiach immunitetu państwa. Sąd Najwyższy podkreślił wagę kwestii przysługiwania stronie pozwanej, jako państwu, immunitetu jurysdykcyjnego, tj. „kwestii ziszczenia się w sprawie przesłanki negatywnej jurysdykcji krajowej w postaci braku wspomnianego immunitetu (zwolnienia spod jurysdykcji krajowej, nie wyrażonego w art. 1111 i 1112 k.p.c., lecz wynikającego z powszechnie przyjętego zwyczaju międzynarodowego)”. Sąd dodał przy tym, że „(t)reść zwyczajowej normy prawa międzynarodowego publicznego statuującej immunitet jurysdykcyjny państwa należy ustalać według kryteriów, które zgodnie z art. 38 ust. 1 lit. b statutu Międzynarodowego Trybunału Sprawiedliwości ${ }^{22}$ decydują o istnieniu prawa zwyczajowego jako źródła prawa międzynarodowego publicznego. Kryteriami tymi są: powszechna praktyka oraz poczucie obowiązku prawnego stosowania się do określonego sposobu postępowania. Materiał do ustaleń w tym względzie stanowią w szczególności postanowienia konwencji bazylejskiej i konwencji Narodów Zjednoczonych, orzecznictwo sądów międzynarodowych, rozstrzygnięcia sądów krajowych, teksty zagranicznych aktów prawnych oraz wypowiedzi piśmiennictwa". Następnie Sąd dokonał wnikliwej analizy wspomnianych wyżej źródeł.

\section{Problemy z określeniem pozwanego}

Jednym z częstych problemów związanych z orzekaniem w sprawach dotyczących immunitetu państwa, a jednocześnie odnoszących się do przedstawicieli dyplomatycznych lub placówek dyplomatycznych jest kwestia prawidłowego wskazania pozwanego. W cytowanych wyżej orzeczeniach z 1958 r., 1987 r.,

${ }^{21}$ W sprawie z powództwa Marii Rotwand przeciwko Skarbowi Państwa - Wojewodzie Mazowieckiemu, Skarbowi Państwa - Prezydentowi miasta stołecznego Warszawa, Miastu Stołecznemu Warszawie oraz Skarbowi Federacji Rosyjskiej - Ambasadzie Federacji Rosyjskiej o ustalenie nieważności umowy cywilnoprawnej (I CK 380/02).

22 Dz. U. z 1947 nr 23, poz. 90 ze zm. 
a także w uchwale z 1990 r. Sądy nie miały trudności z uznaniem, że pozew skierowany przeciwko Konsulatowi czy Ambasadzie jest w istocie pozwem skierowanym przeciwko państwu i kontynuowaniem postępowania.

Wątpliwości pojawiły się natomiast np. w sprawie z powództwa Aleksandra G. przeciwko Ambasadzie Portugalii (postanowienie z 23 września 1998 r. ${ }^{23}$ ). Sąd Rejonowy drobiazgowo przeanalizował ius standi in iudicio państwa obcego i uznał, że misja dyplomatyczna nie ma odrębnej od państwa osobowości prawnej, ,należy przyjmować zatem albo osobowość prawną fiskusa, albo osobowość prawną samego państwa".

Postanowienie Sądu Najwyższego z 2007 r. ${ }^{24}$ jasno pokazuje obecne podejście, pozew nie może być skierowany przeciwko Ambasadzie, powinien być skierowany przeciwko państwu lub przeciwko Skarbowi Państwa. Co więcej, w opinii Sądu, na podstawie obowiązujących przepisów prawa polskiego niedopuszczalne jest usunięcie lub uzupełnienie tego braku.

Sąd Najwyższy, orzekając w postępowaniu kasacyjnym, uznał praktykę polegającą na uznawaniu, że pozew skierowany przeciwko Konsulatowi czy Ambasadzie jest w istocie pozwem skierowanym przeciwko państwu za niewłaściwą, stwierdzając, że „Ambasada państwa obcego w Polsce nie ma zdolności sądowej"25. Powódka po raz pierwszy wszczęła postępowanie przeciwko Ambasadzie w 2004 r., domagając się zasądzenia od Ambasady kwot z tytułu odszkodowania za zniszczenie wynajmowanej na potrzeby strony pozwanej nieruchomości oraz z tytułu przedwczesnego wypowiedzenia umowy najmu. Sąd pierwszej instancji pozew odrzucił, sąd drugiej instancji uznał w rozpoznawanej sprawie istnienie jurysdykcji sądów polskich, przyjął jednak, że pozwana Ambasada nie ma zdolności sądowej, a pozew powinien być skierowany przeciwko Skarbowi Królestwa N. - Ambasadzie Królestwa N. Stwierdził przy tym, że brak zdolności procesowej nie może być usunięty, gdyż nie jest spełniony warunek tożsamości między Ambasadą a Skarbem Królestwa N. W postępowaniu kasacyjnym Sąd Najwyższy potwierdził, że pozew nie może być skierowany przeciwko Ambasadzie, powinien być skierowany w zasadzie przeciwko państwu lub przeciwko Skarbowi Państwa Królestwa N. Niedopuszczalne jest jednak usunięcie lub uzupełnienie tego braku na podstawie obowiązujących przepisów prawa polskiego. „Nie ma także podstaw do uznania - jak uczynił Sąd Najwyższy w orzeczeniu z dnia 26 marca 1958 r. - że powód, wskazując jako stronę pozwaną Ambasadę, pozwał w istocie państwo wysyłające, już bowiem w samym pozwie, sporządzonym przez profesjonalnego pełnomocnika, podkreślono wyraźnie wolę (zamiar) pozwania Ambasady N. (...).” Orzeczenie

${ }^{23}$ Sąd Rejonowy dla m. st. Warszawy, sygn. III C 309/98.

${ }^{24}$ Postanowienie w postępowaniu kasacyjnym z 25 maja 2007 r. I CSK 6/07 w sprawie powództwa Eugenii C. przeciwko Ambasadzie Królestwa N. w W. o zapłatę.

${ }^{25}$ Ibidem. 
opiera się na prawie polskim oraz na prawie międzynarodowym. Sąd jednak nie do końca wykorzystuje prawo międzynarodowe. Jego wypowiedź ogranicza się do nieudokumentowanych, ogólnych stwierdzeń, np. że w literaturze z zakresu prawa międzynarodowego dominuje pogląd, że misje dyplomatyczne nie mają osobowości prawnej w prawie wewnętrznym państwa przyjmującego i nie są uprawnione do wszczynania postępowania procesowego. W zdolność sądową wyposażone są natomiast ,państwa obce jako zagraniczne osoby prawne, działające w postępowaniu cywilnym przez swoje organy". Dalej Sąd Najwyższy dochodzi do wniosku, że „,[m]isja dyplomatyczna - chociaż ma pewną strukturę organizacyjną - nie może być uznana za podmiot odrębny od państwa wysyłającego". Nie przenosi tego jednak na grunt prawa polskiego, konkludując na podstawie przepisów prawa cywilnego (k.c. i k.p.c.), że Ambasada stanowi jedynie „organ państwa wysyłającego działający za granicą”, i nie posiada zdolności sądowej w Polsce.

W sprawie będącej przedmiotem orzeczenia z 13 listopada $2003 \mathrm{r}^{26}$ pozew był, zdaniem sądu, prawidłowo skierowany przeciwko Skarbowi Państwa - Ambasadzie. Podobnie pozew był, w opinii sądu, prawidłowo skierowany w kolejnej sprawie dotyczącej tych samych nieruchomości ${ }^{27}$. Sąd Najwyższy ${ }^{28}$ usiłował także określić w tej sprawie status Przedstawicielstwa Handlowego ZSRR w Warszawie. Sąd stwierdził, że „stanowiło (ono) organ państwa ZSRR działający za granicą", mogło zawrzeć umowę cywilnoprawną o zamianie nieruchomości. Oczywistą wadliwością było natomiast, zdaniem Sądu, wpisanie w księdze wieczystej Ambasady ZSRR, a nie państwa ZSRR jako podmiotu własności nieruchomości. „Ambasada jako stała misja dyplomatyczna stanowi organ zagraniczny państwa bezpośrednio go reprezentujący w stosunkach z innymi państwami. Ambasada nie posiada osobowości prawnej w prawie wewnętrznym państwa przyjmującego, jednak podejmuje czynności (z niewielkimi wyjątkami) w imieniu i na rzecz państwa wysyłającego. Także w tym zakresie istniał zwyczaj i utrwalona praktyka obrotu prawnego".

A zatem sądy polskie uznały w efekcie, że przedstawicielstwo dyplomatyczne nie ma żadnej odrębnej od państwa wysyłającego osobowości prawnej. Każde postępowanie przeciwko przedstawicielstwu dyplomatycznemu jest postępowaniem przeciwko państwu. Wymaga to jednak właściwego sformułowania strony pozwanej i nie może być domniemane z samej istoty przedstawicielstwa dyplomatycznego.

${ }^{26}$ Sprawa z powództwa Marii Rotwand przeciwko Skarbowi Państwa - Wojewodzie Mazowieckiemu, Skarbowi Państwa - Prezydentowi miasta stołecznego Warszawa, Miastu Stołecznemu Warszawie oraz Skarbowi Federacji Rosyjskiej - Ambasadzie Federacji Rosyjskiej o ustalenie nieważności umowy cywilnoprawnej (I CK 380/02).

27 Wyrok z 14 czerwca 2004 r. (I A1707/03).

28 J.w. (I CK 380/02). 


\section{Ochrona majątku misji dyplomatycznej - rozróżnienie immunitetu od jurysdykcji i od egzekucji}

Majątek misji dyplomatycznej, taki jak nieruchomości wykorzystywane na cele dyplomatyczne, urządzenia, środki transportu, rachunki bankowe itp., podlega szczególnej ochronie. Ochrona ta nie obejmuje jednak wszelkich aspektów korzystania z majątku państwa wysyłającego w celu wykonywania funkcji dyplomatycznych. Immunitet państwa i immunitet dyplomatyczny stosowane są tu symultanicznie.

Prawo dyplomatyczne gwarantuje nieruchomościom wykorzystywanym na cele dyplomatyczne, urządzeniom czy środkom transportu, jedynie nietykalność. Art. 22 ust. 3 Konwencji wiedeńskiej z 1961 r. stanowi, że „Pomieszczenia misji, ich urządzenia i inne przedmioty, które się w nich znajdują, oraz środki transportu misji nie podlegają rewizji, rekwizycji, zajęciu lub egzekucji”. Nie wyklucza to możliwości wykonywania jurysdykcji przez państwo przyjmujące w odniesieniu do kwestii związanych np. ze statusem prawnym nieruchomości czy zakupem środków transportu. Jurysdykcję państwa przyjmującego, np. w odniesieniu do nieruchomości ${ }^{29}$ wykorzystywanych na cele dyplomatyczne, potwierdza piśmiennictwo oraz praktyka państw ${ }^{30}$, przede wszystkim zaś Konwencja NZ z 2004 r. Art. 13 Konwencji stwierdza, że immunitet państwa nie obejmuje spraw dotyczących własności, posiadania lub korzystania z nieruchomości położonej na terytorium państwa przyjmującego (podobnie art. 9 Konwencji bazylejskiej z 1972 r.).

Konwencja dotycząca immunitetu państwa jest zgodna z Konwencją wiedeńską z 1961 r. bowiem dalej wyłącza możliwość stosowania środków egzekucji w stosunku do majątku wykorzystywanego na cele dyplomatyczne (art. 21 w związku z art. 19 c). Art. 21 dotyczy majątku (property), „włączając każdy rachunek bankowy, który jest używany lub przeznaczony do użycia (intended for use) w związku z wykonywaniem funkcji misji dyplomatycznej państwa lub jego placówki konsularnej, misji specjalnych, misji przy organizacjach międzynarodowych lub delegacji do organów organizacji międzynarodowych lub na konferencje międzynarodowe".

${ }^{29}$ Przypomnieć można np., że L. Ehrlich (Prawo Narodów, wyd. 3, Kraków, bez daty wyd., s. 98-99) np. stwierdzał, że poprzez nabycie nieruchomości położonej na terytorium innego państwa w drodze kontraktu prywatnoprawnego, a nie umową międzynarodową, państwo nabywające poddaje się orzecznictwu sądów państwa terytorialnego (forum rei sitae), „ponieważ państwo nie może drugiego państwa pozbawić wbrew jego woli władzy nad jego terytorium, co by nastąpiło, gdyby państwo aktem prywatnoprawnym, nie wymagającym zgody tego drugiego państwa, mogło nie tylko nabyć nieruchomość, ale tym samym usunąć ją spod władzy państwa, na którego obszarze ona leży".

${ }^{30} \mathrm{~Np}$. w wyroku z 30 października 1962 r. (BvM 1/60) niemiecki Federalny Sąd Konstytucyjny stwierdził, że nie ma normy prawa międzynarodowego, która zabraniałaby sądom krajowym orzekać w sprawach przeciwko państwu obcemu dotyczących własności gruntu, na którym znajdują się budynki ambasady. 
Prawidłowo zatem Sąd Najwyższy rozpatrywał sprawę dotyczącą ustalenia nieważności umowy cywilnoprawnej dotyczącej nieruchomości rzekomo wykorzystywanych na cele dyplomatyczne w kategoriach immunitetu państwa, a nie immunitetu dyplomatycznego. Sąd uznał swoją jurysdykcję ${ }^{31}$, stwierdzając, że państwo radzieckie, jako strona umowy zamiany nieruchomości z dnia 8 października 1960 r., nie działało jako podmiot stosunków dyplomatycznych, lecz jako podmiot prawa prywatnego (acta iure gestionis), któremu nie przysługuje immunitet jurysdykcyjny. Dalej zauważył, że „Przedmiotem niniejszej sprawy jest ocena ważności i skuteczności tamtej umowy z punktu widzenia cywilnoprawnego, o czym może rozstrzygnąć jedynie sąd cywilny. $Z$ samej istoty takiej sprawy, w której chodzi o przesądzenie stanu prawnego nieruchomości wynika, że zapadły w niej wyrok nie może w żaden sposób naruszać suwerenności obcego państwa (immunitetu państwa), chronionego Konwencją Wiedeńską o stosunkach dyplomatycznych z dnia 18 kwietnia 1961 r. (...), ani immunitetu dyplomatycznego, przysługującego placówce dyplomatycznej i przedstawicielom dyplomatycznym. Tym samym powoływanie się przez pozwany Skarb Państwa Federacji Rosyjskiej na chroniący Ambasadę immunitet dyplomatyczny i jurysdykcyjny jest nietrafne". Pomijając mylne określenie źródła immunitetu państwa w Konwencji z 1961 r., orzeczenie trafnie rozróżnia zakres immunitetu jurysdykcyjnego. W związku z powyższą sprawą w wyroku zaocznym z 24 września 2007 r. ${ }^{32}$ w sprawie z powództwa Skarbu Państwa - Prezydenta Miasta Stołecznego Warszawy przeciwko Skarbowi Państwa Federacji Rosyjskiej - Ambasadorowi Federacji Rosyjskiej w Rzeczypospolitej Polskiej, Sąd Okręgowy w Warszawie nakazał pozwanemu oraz ,wszystkim osobom prawa swoje od niego wywodzącym”, wydanie przedmiotowych nieruchomości, a także zasądził zwrot kosztów postępowania. Orzeczenie to mieści się w dopuszczalnych granicach immunitetu jurysdykcyjnego. Inną kwestią jest kwestia egzekucji.

Sprawa ta ukazuje jeszcze jeden istotny problem prawny. Powstaje na jej gruncie pytanie, czy sądy lub inne organy państwa przyjmującego mają prawo weryfikować sposób korzystania z nieruchomości przez państwo, w tym czy samo stwierdzenie strony pozwanej, że nieruchomość wykorzystywana jest na cele dyplomatyczne jest ostateczne. W przypadku opisywanej nieruchomości pomimo stwierdzenia państwa wysyłającego, że budynki są wykorzystywane na cele dyplomatyczne, nieruchomość jest faktycznie opuszczona i zaniedbana, co więcej nie jest na żadne cele wykorzystywana przez państwo wysyłające.

Gdy chodzi o immunitet egzekucyjny, stanowiska zarówno doktryny, jak i praktyki poszczególnych państw są podzielone ${ }^{33}$. Podczas gdy jeszcze niedawno uważano, że immunitet egzekucyjny ma charakter absolutny, dominuje obecnie

31 Wyrok SN z 13 listopada 2003 r. (I CK 380/02).

${ }^{32}$ II C 1306/06.

${ }_{33}$ H. Fox, The Law of State Immunity, Oxford 2002, s. 368 i nast.; I. Pingel-Lenuzza, Les immunités des États en droit international, Bruxelles 1998, s. 360 i nast., G. M. Badr, State Immunity, The Hague, Boston, Lancaster 1984, s. 107 i nast.; s. 129 i nast. 
pogląd, że również i ten immunitet ma charakter ograniczony (w ten sposób np. Konwencja ONZ z 2007 r., art. 19 i n.). Immunitet egzekucyjny nie ma zastosowania do majątku wykorzystywanego na cele komercyjne. Podkreśla się jednak immunitet egzekucyjny własności misji dyplomatycznej ${ }^{34}$. Innymi słowy, immunitet egzekucyjny chroni jedynie majątek wykorzystywany na cele publiczne, w tym dyplomatyczne. Tak więc, gdy nieruchomość przestaje być używana na cele dyplomatyczne, państwo obce nie może korzystać z immunitetu egzekucyjnego w stosunku do tej własności ${ }^{35}$. Tak np. Niemiecki Federalny Sąd Najwyższy w wyroku z 26 września 1969 r. w sprawie ambasady węgierskiej stwierdził, że gdy nieruchomość przestała być używana na cele dyplomatyczne, immunitet egzekucyjny automatycznie wygasł ${ }^{36}$. Podobnie szwajcarski Trybunał Federalny uznał, że jeśli własność nie ma określonego przeznaczenia, zajęcie jej jest dozwolone ${ }^{37}$.

Warto także zauważyć, że europejska Konwencja o immunitecie państwa z 1972 r. nie zawiera przepisu o immunitecie egzekucyjnym ${ }^{38}$, a opiera się na założeniu, że państwa powinny się porozumieć co do wykonania wyroku. Art. 20 Konwencji zobowiązuje państwo stronę do wykonania ostatecznego wyroku wydanego przeciwko temu państwu przez inną stronę Konwencji.

Interesujące jest w tym kontekście podejście Szwajcarii. Szwajcaria nie rozróżnia immunitetu jurysdykcyjnego i egzekucyjnego. Uznaje natomiast, że wykonanie wyroku jest naturalną konsekwencją jego wydania. Dopuszcza zatem wykonanie wyroku polegającego na zajęciu majątku państwa obcego, w związku $\mathrm{z}$ transakcją prywatnoprawną, o ile roszczenie ma ścisły jurysdykcyjny związek z państwem forum, a majątek nie jest używany na cele misji dyplomatycznej lub inne cele publiczne państwa obcego ${ }^{39}$. W obecnym stanie prawa międzynarodowego takie rozwiązanie jest w pełni dopuszczalne. Tendencja sądów krajowych do ograniczania immunitetu egzekucyjnego ma także swoje logiczne uzasadnienie. Jeśli pozwala się skarżącemu na wniesienie sprawy, rozpatruje się ją co do meritum, naraża się go na wszelkie niedogodności i koszty związane z postępowaniem, to nielogiczne jest odmówienie mu środka prawnego, gdy wygra sprawę ${ }^{40}$.

${ }^{34} \mathrm{~Np}$. art. 21 Konwencji ONZ z 2007 r.

${ }^{35}$ W ten sposób wyraźnie D. Chamlongrasdr, Foreign State Immunity and Arbitration, London 2007, s. 300.

3665 ILR, s. 110, 113, cytuję za D. Chamlongrasdr, op. cit., s. 300.

37 United Arab Republic v. Dane X., wyrok z 10 lutego 1960 r., 65 ILR 385, 392, podaję za D. Chamlongrasdr, op. cit., s. 26, por. s. 42-43, 269.

${ }^{38}$ Powody wyjaśnia m.in. G. M. Badr, op. cit., s. 129 i nast.

${ }^{39}$ Zob. orzeczenie Trybunału Federalnego Kingdom of Greece v. Julius Bar and Co., wyrok z 6 czerwca 1956 r., ATF 82 (1956) 75, 23 ILR 195, i inne cytowane przez H. Fox, op. cit., s. $374-378$.

${ }^{40}$ Zob. J. Bröhmer, State Immunity and the Violation of Human Rights, The Hague, Boston, London 1997, s. 23. 
I. Brownlie wskazuje dobitnie, że silne argumenty przemawiają za zasadą, że jeśli państwo może wykonywać jurysdykcję i wydać orzeczenie, to możliwa jest także egzekucja wyroku (there are strong considerations of principle which militate in favor of the view that, if there is a competence of the municipal legal system in order to exercise jurisdiction and to render a judgment, enforcement jurisdiction in respect of that judgment should also be exercisable $)^{41}$. Ten sam autor podkreśla dalej, że praktyka sądowa przyjmuje obecnie stanowisko, że kryteria kompetencji sądów krajowych są co do zasady takie same, gdy chodzi o wykonanie wyroku/egzekucję i jurysdykcję ${ }^{42}$.

Konkludując, immunitet jurysdykcyjny nie przysługuje w odniesieniu do własności czy posiadania nieruchomości i spraw z nią związanych (kontrakty dotyczące dostarczania energii elektrycznej, gazu, usług itp.), o ile wykonywanie jurysdykcji państwa forum nie zakłóca działania misji, natomiast działa immunitet egzekucyjny. Immunitet egzekucyjny dotyczy ściśle majątku niezbędnego do wykonywania celów dyplomatycznych czy konsularnych.

\section{Kontrakty zatrudnienia}

Innym obszarem, w którym immunitet państwa „miesza się” z immunitetami dyplomatycznymi czy konsularnymi są sprawy związane z kontraktami zatrudnienia w ambasadach lub placówkach konsularnych. Kwestie zatrudnienia w placówkach dyplomatycznych lub konsularnych nie są uregulowane w Konwencjach wiedeńskich z 1961 r. lub 1963 r. Gdy chodzi o immunitet państwa, niektóre $\mathrm{z}$ tych kontraktów, jako acta de iure gestionis, podlegają jurysdykcji państwa forum. Praktyka państw europejskich najczęściej opiera się na rozróżnieniu charakteru wykonywanych czynności w ramach danego stosunku pracy. Wyrazem tej praktyki jest orzeczenie Europejskiego Trybunału Praw Człowieka z dnia 23 marca 2010 r. w sprawie 15869/02 Cudak v. Litwie, dotyczące molestowania Litwinki zatrudnionej w polskiej ambasadzie w Wilnie przez jednego z pracowników tej ambasady. ETPC uznał, że sądy litewskie, przyznając Polsce immunitet państwa w tej sprawie, nie zachowały rozsądnego stosunku proporcjonalności, przekroczyły zakres swobody uznania i w ten sposób naruszyły istotę prawa do sądu skarżącej. Podstawą do takiej sentencji było uznanie, że współcześnie immunitet państwa nie przysługuje w odniesieniu do czynności de iure gestionis, tj. kwestii zatrudnienia ( $w$ tym zwolnienia z pracy) na stanowisku niezwiązanym $\mathrm{z}$ wykonywaniem funkcji władczych $\mathrm{w}$ ambasadzie. Trybunał podkreślił zresztą,

${ }^{41}$ I. Brownlie, op. cit., s. 342.

42 Ibidem, s. 343, zob. cytowane orzeczenia przypis 117. 
że nie chodzi nawet o to, czy skarżąca wykonująca funkcje sekretarskie i telefonistki miała dostęp do pewnych dokumentów czy poufnych rozmów podczas wykonywania swoich obowiązków, lecz o fakt, że podstawą sporu jest zwolnienie z pracy w związku z molestowaniem seksualnym. Takie akty z trudem mogą być uważane za godzące $w$ interesy bezpieczeństwa Polski (pkt. 72-74). Trybunał oparł się na art. 11 Konwencji NZ z 2004 r., przyjmując, że wyraża on obecnie prawo zwyczajowe w tej dziedzinie.

W latach 90. Sądy polskie w ogóle nie kwalifikowały spraw dotyczących zatrudnienia w ambasadach jako spraw z zakresu immunitetu państwa. W sprawie Stawomir S. przeciwko Ambasadzie ChRL o wynagrodzenie za okres wypowiedzenia oraz zasądzenie wyrównania na poczet ubezpieczenia społecznego, Sąd Rejonowy dla Warszawy Pragi w postanowieniu z 27 kwietnia 1998 r. odrzucił pozew, ponieważ w opinii sądu, zgodnie z art. 1111 k.p.c. nie mogą być pozywani przed sądy polskie uwierzytelnieni w RP szefowie przedstawicielstw dyplomatycznych państw obcych, osoby należące do personelu dyplomatycznego oraz inne osoby korzystające z immunitetów dyplomatycznych. Rozumowanie sądu jest typowe - ponieważ osoby te wchodzą w skład misji, jednostek uprawnionych do reprezentowania państwa, w tym do dokonywania czynności procesowych i występowania przed sądem, to jurysdykcji sądów polskich nie podlega również sama misja ${ }^{43}$. Podobnie Sąd Rejonowy dla Warszawy Pragi w postanowieniu z 14 kwietnia 1993 r. w sprawie Barbary J. przeciwko Ambasadzie Królestwa Belgii o przywrócenie do pracy ${ }^{44}$ stwierdził brak jurysdykcji krajowej na podstawie art. 1111 ust. 1 pkt. 1 k.p.c., choć pozwana była ambasada. W sprawie Marii K. przeciwko Ambasadorowi Republiki Austrii o przywrócenie do pracy i zasądzenie wynagrodzenia ${ }^{45}$ sąd ustalił co prawda, że Maria K. zatrudniona była na podstawie umowy o pracę w ambasadzie, pełniąc swoje obowiązki w rezydencji ambasadora, stwierdził jednak, że zgodnie z Konwencją z 1961 r. zarówno ambasada, jak i ambasador korzystają z immunitetu dyplomatycznego. „Zatrudnienie powódki przez urząd Ambasadora powoduje, że zgodnie z art. $1111 \S 1$ sprawa wyłączona jest spod jurysdykcji krajowej".

Dopiero cytowane wyżej postanowienie SN z 11 stycznia $2000 \mathrm{r}^{46} \mathrm{~W}$ sprawie M. K. przeciwko Ambasadzie Republiki Chile o uznanie bezskuteczności wypowiedzenia umowy o pracę opiera się na immunitecie państwa, a nie immunitecie dyplomatycznym, i w konsekwencji dopuszcza jurysdykcję polskiego sądu na tej podstawie, że stosunki pracy stanowią czynności o charakterze prywatnoprawnym (de iure gestionis). Orzeczenie nie wchodzi jednak w zawiłości charakteru stosunku pracy w tej konkretnej sprawie.

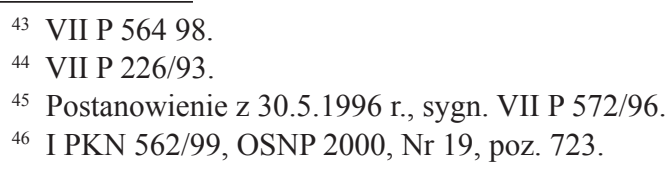




\section{Wyrok zaoczny i problemy z doręczaniem wyroków}

Postępowania w sprawach dotyczących obcych przedstawicielstw dyplomatycznych czy konsularnych lub w innych sprawach dotyczących immunitetu państwa często prowadzone są pod nieobecność przedstawicieli pozwanego państwa. W ten sposób bywa demonstrowane przekonanie, że państwo korzysta w danej sprawie z immunitetu. Pojawia się więc kwestia np. skutecznego doręczenia wyroku państwu obcemu. Konwencja wiedeńska z 1961 r. nie normuje tych kwestii. Natomiast normuje je art. 22 Konwencji NZ z 2004 r., który postanawia, że w braku umowy lub specjalnych uzgodnień między stronami, doręczenie powinno nastąpić kanałami dyplomatycznymi, tj. poprzez przekazanie przez przedstawiciela dyplomatycznego państwa przyjmującego ministerstwu spraw zagranicznych państwa wysyłającego. Art. 22 dodaje, że doręczenie może nastąpić także ,,wszelkimi innymi sposobami zaakceptowanymi przez zainteresowane państwo, jeśli nie są zakazane przez państwo forum". Art. 22 jest rezultatem kompromisu i udaną próbą sformułowania najbardziej racjonalnego sposobu doręczenia. Niekiedy jednak sądy mogą mieć trudności z określeniem prawidłowego sposobu doręczenia o czym świadczy chociażby przypadek wyroku zaocznego Sądu Najwyższego z dnia 24 września 2007 r. wzywającego Federację Rosyjską do wydania nieruchomości ${ }^{47}$ oraz dotyczący w istocie tej samej sprawy (powiązanej nieruchomości) wyrok z dnia 9 czerwca 2009 r. ${ }^{48}$ Początkowo sąd uznawał, że specjalne doręczenie wyroku nie jest konieczne, skoro strona rosyjska uczestniczyła do pewnego momentu w postępowaniach sądowych. Zresztą w postanowieniu z 17 czerwca 2009 r. dotyczącym sprostowania błędu pisarskiego we wcześniejszym wyroku ${ }^{49}$ Sąd odnotował ,prawidłowe doręczenie odpisu pozwu z załącznikami oraz zawiadomienia i pouczenia (zwrotne potwierdzenie odbioru k. 180). Później jednak uznano, że wyroki dotyczące wydania nieruchomości powinny zostać doręczone zgodnie z prawem międzynarodowym, tj. zgodnie z Konwencją haską z dnia 15 listopada 1965 r. o doręczaniu za granicą dokumentów sądowych i pozasądowych w sprawach cywilnych lub handlowych, sporządzonej w Hadze dnia 15 listopada $1965 \mathrm{r}^{50}$

Doręczanie pozwów w sprawach związanych z immunitetem państwa na podstawie Konwencji haskiej nie jest najlepszym rozwiązaniem. Konwencja haska nie dotyczy bowiem państw, z założenia dotyczy sporów między osobami fizycznymi lub prawnymi w sprawach cywilnych. Państwa często zatem nie przyjmują do wiadomości dokumentów przedstawionych im zgodnie z Konwencją. Tak zresztą jak miało to miejsce w przypadku sprawy Natoniewskiego. Z faktów opisywanych

\footnotetext{
${ }^{47}$ II C 1306/06.

48 IC $1909 / 05$.

49 I C 1909/05.

${ }^{50}$ Dz. U. z 2000 r. nr 87, poz. 968.
} 
w orzeczeniu wynika, że Sąd Apelacyjny podjął próbę doręczenia postanowienia z dnia 13 maja 2008 r. i skargi kasacyjnej powoda na to postanowienie w trybie określonym przepisami Konwencji haskiej, lecz próba ta się nie powiodła. Strona niemiecka odmówiła przyjęcia dokumentów ze względu na pozostawanie sprawy, zgodnie z opinią organów niemieckich, poza przedmiotowymi granicami zastosowania konwencji, określonymi w art. 1 ust. 1. Dokumenty sądowe dostarczono następnie drogą dyplomatyczną opisaną w konwencji NZ z 2004 r. ${ }^{51}$ Ministerstwo Spraw Zagranicznych RFN zachowało się w typowy w takich sprawach sposób, zwróciło dokumenty wraz z notą informującą, że dokonane doręczenie narusza immunitet jurysdykcyjny Republiki Federalnej Niemiec, gdyż sprawa dotyczy działań de iure imperium, czyli działań władczych państwa.

Sąd Najwyższy, oceniając tę sytuację, słusznie zauważył, że kwestia doręczenia nie jest uregulowana ani w wiążących Polskę umowach międzynarodowych, ani w prawie polskim. Poszukiwał zatem własnych rozwiązań, opartych na praktyce międzynarodowej i uznał, że doręczenie drogą dyplomatyczną stronie pozwanej odpowiednich postanowień Sądu Apelacyjnego było skutecznie dokonane z chwilą otrzymania przesyłki przez Ministerstwo Spraw Zagranicznych Republiki Federalnej Niemiec. Zdaniem Sądu: ,zajęcie odmiennego stanowiska oznaczałoby uzależnienie kontynuowania postępowania sądowego od decyzji pozwanego państwa, a tego nie można zaakceptować, ponieważ współcześnie ochrona immunitetowa przed sądem zagranicznym jest udzielana państwom (...) nie we wszystkich sprawach, a jedynie w określonej ich kategorii. Przekazanie pozwanemu państwu przesyłki w omawiany sposób w pełni przy tym urzeczywistnia cele instytucji doręczenia w postępowaniu cywilnym. W świetle prawa międzynarodowego publicznego, ministrowi spraw zagranicznych przysługuje ogólna kompetencja do reprezentowania państwa w stosunkach z zagranicą (por. art. 7 ust. 2 lit. a Konwencji wiedeńskiej o prawie traktatów, sporządzonej dnia 23 maja 1969 r. (Dz. U. z 1990 r. nr 74, poz. 439). Przekazanie przesyłki ministerstwu spraw zagranicznych zapewnia zatem państwu pozwanemu uzyskanie wiedzy o toczącym się postępowaniu i podjęcie obrony swych praw. Wymaga podkreślenia, że doręczanie pism sądowych i procesowych państwu pozwanemu drogą dyplomatyczną jest szeroko akceptowane w praktyce międzynarodowej, czego potwierdzeniem są nie tylko powołane wyżej umowy międzynarodowe dotyczące immunitetu państwa (konwencja bazylejska i konwencja Narodów Zjednoczonych), ale i przepisy ustaw krajowych (np. art. 12 ust. 1 brytyjskiej ustawy o immunitecie państwa z 1978 r. - załącznik nr 12 do pisma Ministerstwa Sprawiedliwości z 26.2.2010 r., art. 24 australijskiej ustawy o immunitecie państwa z 1985 r. - załącznik nr 15 do pisma

${ }^{51}$ Sąd Najwyższy słusznie także uznał próbę dostarczenia dokumentów sadowych na podstawie rozporządzenia $\mathrm{nr}$ 1348/00 za nieprawidłową, gdyż ma ono zastosowanie tylko w sprawach cywilnych i handlowych (art. 1 ust. 1). 
Ministerstwa Sprawiedliwości z 26.2.2010 r., oraz art. 13 ust. 1 południowoafrykańskiej ustawy o immunitecie państw z 1981 r. - pkt II pisma Ministerstwa Sprawiedliwości z 26.2.2010 r.)”.

Sąd Najwyższy uznał w tej sprawie, że niektóre dokumenty sądowe nie zostały jednak właściwie doręczone stronie pozwanej, ale nie stworzyło to podstaw do przyjęcia, że strona pozwana została z tego powodu pozbawiona możności obrony swych praw w rozumieniu art. 379 pkt 5 k.p.c. Sąd uwzględnił przy tym zachowanie strony pozwanej w sprawie i stwierdził, że z noty dyplomatycznej Ministerstwa Spraw Zagranicznych Republiki Federalnej Niemiec „wynika jednoznacznie, że w takich sprawach jak niniejsza samo już doręczenie pozwanemu państwu pism sądowych i procesowych jest traktowane przez Republikę Federalną Niemiec jako naruszenie immunitetu jurysdykcyjnego państwa. Treść tej noty pozwala przyjąć z prawdopodobieństwem graniczącym z pewnością, że gdyby nawet Sąd Okręgowy dokonał doręczenia drogą dyplomatyczną, wysłana przesyłka zostałaby zwrócona, a strona pozwana nie wzięłaby udziału w postępowaniu". Stwierdzenia te pozwoliły Sądowi na kontynuowanie postępowania i rozstrzygnięcie w kwestii istnienia immunitetu państwa.

\section{Zrzeczenie się immunitetu}

Inną kwestią związaną z odróżnieniem immunitetów dyplomatycznych i immunitetu państwa jest kwestia zrzeczenia się immunitetu. Art. 32 Konwencji wiedeńskiej z 1961 r. wskazuje, że:

„1. Państwo wysyłające może zrzec się immunitetu jurysdykcyjnego swoich przedstawicieli dyplomatycznych oraz osób korzystających z immunitetu na podstawie artykułu 37.

2. Zrzeczenie się powinno być zawsze wyraźne.

3. Jeżeli przedstawiciel dyplomatyczny lub osoba korzystająca z immunitetu jurysdykcyjnego na podstawie artykułu 37 wszczyna postępowanie, nie będzie już dopuszczalne powoływanie się na immunitet jurysdykcyjny w stosunku do powództw wzajemnych bezpośrednio związanych z powództwem głównym.

4. Zrzeczenie się immunitetu jurysdykcyjnego w postępowaniu cywilnym lub administracyjnym nie jest uważane za domniemane zrzeczenie się immunitetu w stosunku do wykonania wyroku, co wymaga oddzielnego zrzeczenia się".

Przepis ten jasno wskazuje, że dyplomata sam nie może zrzec się immunitetu, zrzeczenie musi być dokonane przez państwo czy w imieniu państwa. Ponadto zrzeczenie się przez państwo immunitetu jurysdykcyjnego w takich sprawach nie oznacza zrzeczenia się immunitetu egzekucyjnego. 
Zgodnie z kolei z przepisami odnoszącymi się do immunitetu państwa, zrzeczenie się immunitetu państwa zarówno jurysdykcyjnego, jak i egzekucyjnego (muszą one być osobne) może nastąpić m.in. w traktacie, notą dyplomatyczną, w pisemnym kontrakcie, $w$ drodze oświadczenia złożonego przed sądem lub poprzez rzeczywiste poddanie się postępowaniu sądowemu (np. art. 7 Konwencji NZ z 2004 r.). A zatem, rozwiązania dotyczące zrzeczenia się immunitetów są podobne.

Sądy polskie kilka razy zajmowały się tymi kwestiami, między innymi w postanowieniu z 23 września 1998 r. w sprawie Aleksander G. przeciwko Ambasadzie Portugalii Sąd zauważył, że zrzeczenie się immunitetu uruchamia procedurę krajową oraz że może ono nastąpić poprzez zawarcie odpowiedniej klauzuli prorogacyjnej w kontrakcie cywilnoprawnym, w tym przypadku była to umowa najmu, w której strony wskazały, iż w przypadku sporu właściwym do jego rozpoznania będzie sąd rejonowy dla $\mathrm{m} / \mathrm{st}^{\text {. Warszawy }}{ }^{52}$. Ponieważ jednak powód wszedł w uprawnienia wynajmującego (wierzyciela) na skutek umowy cesji, której najemca, Ambasada Portugalii, nie była stroną, przeto klauzula prorogacyjna zawarta w umowie najmu nie mogła w tej konkretnej sprawie wywołać skutków prawnych wobec najemcy; procesowe uprawnienie do pozywania przed sąd krajowy nabyte drogą umowy było bowiem, w opinii sądu, niezbywalne.

Inna z kolei kwestia związana ze zrzeczeniem się immunitetu państwa rozważana była w orzeczeniu 29 października 2010 r. w sprawie Natoniewskiego ${ }^{53}$. Sąd Najwyższy odniósł się w nim bowiem do pojawiających się w doktrynie poglądów usiłujących usprawiedliwić jurysdykcję państwa forum m.in. w stosunku do działań państwa obcego stanowiących poważne naruszenia praw człowieka (np. zbrodnie wojenne, tortury), a także norm o charakterze ius cogens. Sąd odwołał się do praktyki międzynarodowej i podzielił opinię sądów innych państw, które zakwestionowały zasadność poglądów o domyślnym zrzeczeniu się immunitetu przez państwo w tego typu przypadkach. Zrzeczenie to miałoby być skutkiem bądź działania państwa w sposób sprzeczny z normami imperatywnymi, bądź skutkiem przystąpienia przez państwo do umowy międzynarodowej dotyczącej ochrony praw człowieka. Sąd Najwyższy podkreślił, że „Koncepcja pierwsza opiera się na całkowicie dowolnym założeniu - nie uwzględnia tego, że rezygnacja przez państwo z immunitetu musi, tak jak złożenie każdego innego oświadczenia woli, nastąpić w sposób dostatecznie wyraźny, drugą zaś koncepcję trudno

${ }^{52}$ A. Grabiński wniósł pozew o zapłatę czynszu za najem nieruchomości przeciwko Ambasadzie Portugalii zajmującej pomieszczenia biurowe na podstawie umowy najmu zawartej z Przedsiębiorstwem „Dipservice” w Warszawie, po którym na mocy umowy cesji z 25.3.1996 r. powód przejął uprawnienia wynajmującego. Zdaniem powoda najemca - Ambasada Portugalii - opuszczając nieruchomość pozostawiła ją w złym stanie technicznym, co na podstawie $\S 4$ umowy najmu skutkuje powstaniem roszczenia o zwrot kosztów remontu i o czynsz za czas jego trwania, nie dłuższy jednak niż jeden miesiąc.

${ }_{53}$ IV CSK 465/09. 
pogodzić z wymaganiami prawa traktatów w zakresie odnoszącym się do przystąpienia państwa do umowy międzynarodowej”. Sąd słusznie dalej zauważył, że teza o domyślnym zrzeczeniu się immunitetu nie znajduje poparcia w praktyce międzynarodowej, przywołał przy tym orzeczenie włoskiego sądu z 11 marca 2004 r. w sprawie Ferrini v. Republice Federalnej Niemiec, amerykańskiego sądu apelacyjnego z 1 lipca 1994 r. w sprawie Hugo Princz v. Republice Federalnej Niemiec, wyrok z 8 kwietnia 1997 r. w sprawie Hirsz v. Republice Federalnej Niemiec i Izraelowi, wyrok z 26 listopada 1996 r. oraz z 10 lutego 1997 r. w sprawie Smith v. Libii, dotyczącym katastrofy lotniczej nad Lockerbie.

\section{Wnioski}

Teoretyczne rozróżnienie immunitetu państwa i immunitetów dyplomatycznych nie jest skomplikowane. W praktyce jednak sądy mają trudności w rozpoznaniu tych różnic i zastosowaniu właściwej formuły do konkretnej sytuacji. Najtrudniejszymi przypadkami wydają się być dla sądów sprawy dotyczące przedstawicieli dyplomatycznych lub pomieszczeń misji dyplomatycznych (placówek konsularnych), ich majątku, zatrudnienia w misjach lub konsulatach itp. Misje dyplomatyczne, placówki konsularne i inne misje nie korzystają z odrębnej od państwa wysyłającego osobowości prawnej. Było to podkreślane i w orzecznictwie polskim i innych państw europejskich, w sprawach wnoszonych przeciwko przedstawicielom dyplomatycznym, ambasadom, konsulatom itp. W konsekwencji czasami uznawano, że pozwanym jest w istocie państwo, lub też odrzucano pozew, często błędnie przyjmując, że zastosowanie mają immunitety dyplomatyczne. Ostatnie orzeczenia, w szczególności orzeczenie w sprawie Natoniewskiego, pokazują, że polskie sądy zaczynają coraz lepiej radzić sobie z problemami immunitetu państwa. 